\title{
Implementation of Filter Picker Algorithm for Identification of the 2018 Aftershock Lombok Earthquake
}

\author{
Implementasi Algoritma Filter Picker untuk Identifikasi Kejadian Aftershock Gempa Lombok 2018
}

\author{
Ardianto*1 $^{* 1}$ Husni Y. M. ${ }^{1}$, Nugraha A. D. ${ }^{2}$, Muzli M. ${ }^{3,4}$, Zulfakriza Z ${ }^{2}$. Afif H..$^{5,6}$, 6, Sahara D. P. ${ }^{2}$ \\ Widiyantoro S. ${ }^{2}$, Priyono A. ${ }^{2}$, Puspito N. T. ${ }^{2}$, Supendi P., ${ }^{3}$, Riyanto A. ${ }^{3}$, Wei S. ${ }^{4}$, Prabowo B. S. ${ }^{1}$ \\ ${ }^{1}$ Lab Vulkanologi dan Panas Bumi, Teknik Geofisika, Fakultas Teknik Pertambangan dan Perminyakan, \\ Institut Teknologi Bandung (ITB), Bandung, Indonesia \\ ${ }^{2}$ Kelompok Keahlian Geofisika Global, Fakultas Teknik Pertambangan dan Perminyakan, Institut Teknologi Bandung \\ ${ }^{3}$ Badan Meteorologi, Klimatologi, dan Geofisika (BMKG), Jakarta, Indonesia \\ ${ }^{4}$ Earth Observatory of Singapore (EOS), Nanyang Technological University Singapore \\ ${ }^{5}$ Pusat Vulkanologi dan Mitigasi Bencana Geologi (PVMBG), Bandung, Indonesia \\ ${ }^{6}$ Program Magister Sains Kebumian, Fakultas Ilmu dan Teknologi Kebumian, Institut Teknologi Bandung (ITB), Bandung, Indonesia \\ ${ }^{7}$ Program Doktor Teknik Geofisika, Fakultas Teknik Pertambangan dan Perminyakan, Institut Teknologi Bandung (ITB), \\ Bandung, Indonesia \\ *Email: ardiantoosman4@gmail.com
}

Submit: 22 Agustus 2019; Revised: 30 Agustus 2019; Accepted: 3 September 2019

\begin{abstract}
The ability to identify earthquake events that are consistent, efficient and accurate is increasingly needed along with the increase in the amount of data analyzed. In this paper a filter picker algorithm is implemented to identify aftershock events and determination of arrival time automatically, especially for the $P$ wave phase. Here modifications are made in determining the uncertainty of arrival time and there are additional criteria in determining the time of arrival used. The arrival time uncertainty will depend on parameters related to the clarity of the $P$ wave onset. The additional criteria are that in a certain time span, there are at least 5 stations determined by the time the filter picker arrives. This is done to minimize identification errors due to local noise and other practical reasons, namely the minimum number of stations to determine the location and other seismological analysis. In order to test the filter picker algorithm,we used aftershock data from the Lombok earthquake occurred on July 29 (M 6.4), August 5 (M 7), and August 19 ( $M$ 6.3 and $M$ 6.9) 2018. The aftershock data was used for 30 days long, from August 4, 2018 to September 4, 2018 using local seismic station in Lombok Island. The results of the filter picker algorithm were evaluated by comparing the number of earthquake events detected and the accuracy of determining the $P$ wave arrival time automatically to the results of manually arriving time. In addition, a comparison of the results obtained from a broadband type seismometer with a short period is used to find out how much influence the type of tool has on its performance results. The results of the comparison with the manual arrival time show that more than 85 percent of the results of the automatic arrival time have a difference below 0.2 seconds. The filter picker algorithm is quite effective for identifying events and determining the arrival time of $P$ waves. In this paper it is also shown that this algorithm can be used for broad band and
\end{abstract}

short period seismometer sensor, even without the prior correction of instruments.

Keywords: rupture, $T_{d} u r$, Palu-Donggala earthquake, $H C$ plot

Abstrak: Kemampuan untuk melakukan identifikasi kejadian gempa yang konsisten, efisien dan akurat menjadi semakin dibutuhkan seiring dengan peningkatan jumlah data yang dianalisa. Pada makalah ini, kami mengimplementasikan algoritma filter picker untuk melakukan identifikasi kejadian gempa susulan dan penentuan waktu tiba secara ototmatis, khususnya untuk fasa gelombang P menggunakan jaringan stasiun lokal. Pada studi ini dilakukan modifikasi dalam penentuan ketidakpastian waktu tiba dan terdapat penambahan kriteria dalam menentukan waktu tiba yang digunakan. Nilai dari ketidakpastian waktu tiba yang ditentukan akan bergantung kepada parameter yang berkaitan dengan kejelasan onset dari fasa gelombang P. Kriteria tambahan dalam penentuan waktu tibanya adalah dalam suatu rentang waktu tertentu, minimal terdapat 5 stasiun yang ditentukan waktu tibanya oleh filter picker. Hal ini dilakukan untuk meminimumkan kesalahan identifikasi event akibat adanya noise lokal dan jumlah stasiun minimum untuk melakukan penentuan lokasi dan analisa seismologi lainya. Untuk mengevaluasi performa algoritma filter picker ini digunakan data aftershock dari gempa kuat Lombok yang terjadi pada tanggal 29 Juli (M 6.4), 5 Agustus (M 7) dan 19 Agustus (M 6.3 dan M 6.9) 2018. Rekaman data gempagempa aftershock yang digunakan selama 30 hari, dari tanggal 4 Agustus 2018 sampai dengan 4 September 2018, menggunakan jaringan stasiun lokal di Pulau Lombok. Hasil dari algoritma filter picker dievaluasi dengan membandingkan jumlah kejadian gempa yang terdeteksi dan keakuratan penentuan waktu tiba gelombang $\mathrm{P}$ terhadap hasil dari penentuan waktu tiba secara manual. Selain itu juga dilakukan 
perbandingan hasil yang didapatkan dari seismometer tipe broadband dengan short period untuk mengetahui seberapa besar pengaruh tipe alat terhadap hasil kinerjanya. Hasil perbandingan penentuan otomatis menggunakan filter picker dengan penentuan waktu tiba manual menunjukan bahwa lebih dari 85 persen hasil penentuan waktu tiba otomatis memiliki selisih dibawah 0.2 detik. Oleh karena itu dapat dikatakan bahwa algoritma filter picker cukup efektif untuk identifikasi event dan penentuan waktu tiba gelombang P. Pada makalah ini juga ditunjukan bahwa algoritma ini dapat digunakan untuk sensor seismometer bertipe broad band dan short period, meskipun tanpa adanya proses koreksi instrument sebelumnya.

Kata kunci: Identifikasi kejadian aftershock, gempa Lombok 2018, penentuan waktu tiba otomatis, filter picker

\section{PENDAHULUAN}

Penentuan waktu tiba merupakan hal mendasar dalam melakukan analisis seismologi, terutama karena penyederhanaan masalah menggunakan pendekatan sinar gelombang masih merupakan pendekatan yang paling umum digunakan. Kualitas analisis dan interpretasi sangat bergantung kepada kualitas penentuan waktu tiba dari fase gelombang ( $\mathrm{P}$ dan $\mathrm{S}$ ), selain jumlah dan cakupan spasial stasiun, model kecepatan, ataupun parameter model lainnya. Peningkatan jumlah stasiun seismograf dan data gempa yang terekam setiap harinya serta kemampuan komputasi yang semakin membaik membuat proses otomasi penentuan waktu tiba fase gelombang menjadi semakin sangat penting dan menarik. Proses otomatisasi dilakukan untuk meningkatkan efisiensi dalam melakukan analisis seismologi serta mengatasi masalah subjektifitas dan konsistensi dalam melakukan penentuan waktu tiba. Tetapi tentu saja saat ini belum terdapat algoritma yang kualitas hasilnya melebihi manusia yang sudah terlatih. Oleh karena itu algoritmaalgoritma yang ada saat ini sebenarnya mencoba meniru sebaik mungkin dari proses berpikir manusia saat melakukan penentuan waktu tiba.

Saat ini ada banyak algoritma yang berkembang untuk penentuan waktu tiba atau identifikasi jenis gempa yang terjadi secara otomatis, yang bekerja dalam domain waktu maupun frekuensi. Beberapa contoh algoritma ini ada yang berkerja berdasarkan nilai energi gelombang atau amplitudo (Earle dan Shearer, 1994; Han dkk., 2009), polarisasi dari gelombang (Ross dan Ben-Zion, 2014), parameter statistik (Baillard dkk., 2014), AIC (Leonard dan Kennett, 1999), dan kemiripan sinyal berdasarkan koefisien korelasi silang (De Meersman dkk., 2009). Pada makalah ini digunakan algoritma filter picker yang diajukan oleh Lomax dkk. pada tahun 2012 untuk melakukan penentuan waktu tiba gelombang P. Secara umum metode ini menyerupai metode Allen picker (1978) yang memanfaatkan turunan dari seismogram untuk meningkatkan sensitifitas terhadap frekuensi tinggi, serta metode oleh Baer-Kradolfer tahun 1987 yang memanfaatkan nilai standar deviasi dan rata-rata window untuk mengubah kurva karakteristik secara dinamis. Prinsip utama yang membuat algoritma ini menarik adalah memanfaatkan berbagai nilai band frekuensi untuk membentuk suatu kurva karakteristik. Selanjutnya akan dilakukan evaluasi performa dari algoritma ini, dengan membandingkan



Gambar 1. Peta daerah penelitian serta lokasi penempatan seismometer broad band (segitiga terbalik berwarna biru), short period (segitiga terbalik berwarna merah), dan seismometer permanen (segitiga permannen berwarna hitam), dan bintang berwarna kuning merupakan lokasi episenter gempa signifikan yang terjadi menurut BMKG (Badan Meteorologi Klimatologi dan Geofisika).

hasil dari penentuan waktu tiba otomatis dengan yang sudah ditentukan secara manual sebelumnya.

\section{DATA DAN METODELOGI}

\subsection{Data}

Data yang digunakan adalah data aftershock dari rangkaian gempa kuat Lombok yang terjadi pada tanggal 29 Juli (M 6.4), 5 Agustus (M 7) dan 19 Agustus (M 6.3 dan M 6.9) 2018. Penelitian ini menggunakan data rekaman yang diambil dalam rentang waktu 4 Agustus 2018 sampai dengan 4 September 2018. Instrument yang digunakan adalah stasiun seismograf temporer kerjasama antara Institut Tekbologi Bandung (ITB), Badan Meteorologi Klimatologi dan Geofisika (BMKG) dan Earth Observatory of Singapore (EOS) (10 seismometer broad band dan 6 seismometer short period) dan 4 seismograf permanen dari stasiun pengamatan Pusat Vulkanologi dan Mitigasi Bencana Geologi (PVMBG) di sekitar Gunung Rinjani. Sampling frekuensi yang digunakan adalah $100 \mathrm{~Hz}$. Semua stasiun mempunyai sensor tiga komponen, tetapi yang digunakan untuk proses identifikasi kejadian gempa hanya komponen vertikal saja. Instrumen yang ada dipasang secara menyebar meliputi seluruh pulau Lombok, hal ini dilakukan untuk menjamin cakupan stasiun yang baik dari gempa-gempa aftershock yang terjadi. Distribusi stasiun seismograf di pulau Lombok dapat dilihat pada Gambar 1.

\subsection{Algoritma Penentuan Waktu Tiba}

Pengolahan data pertama-tama adalah melakukan penghilangan trend data rekaman dan melakukan pengurangan 


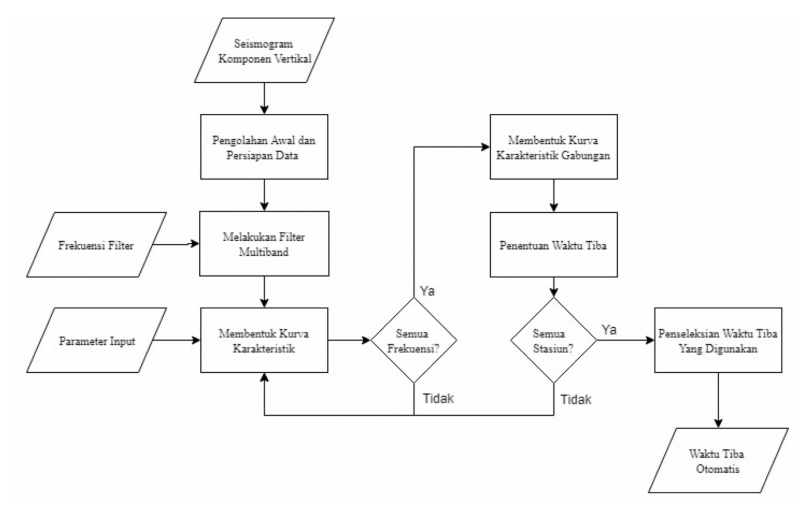

Gambar 2. Diagram alir penentuan waktu tiba secara otomatis menggunakan algoritma filter picker pada penelitian ini.

dengan nilai rata-rata data rekaman, sehingga data rekaman menjadi stasioner. Kemudian data rekaman tersebut dipotong per 10 menit, tujuan pemotongan rekaman adalah untuk mempermudah proses penentuan waktu tiba selanjutnya. Pemotongan data rekaman ini tidak mempengaruhi hasil dari identifikasi event yang dilakukan selanjutnya, tetapi dapat mempengaruhi efisiensi proses yang dilakukan. Pada Makalah ini tidak diaplikasikan proses penghilangan respon instrument dan filter frekuensi, sehingga dapat diuji sejauh mana algoritma dapat diaplikasikan ini saat melakukan pengamatan secara realtime.

Pada makalah ini hanya akan difokuskan pada tahapantahapan utama dalam menentukan waktu tiba menggunakan filter picker, untuk informasi lebih detil mengenai algoritma ini sudah dijelaskan secara baik pada makalah hasil penelitian oleh Lomax dkk. (2012). Proses pengerjaan atau algoritma dari filter picker meliputi proses multiband filtering, pembuatan fungsi karakteristik dari sinyal dan terakhir adalah penentuan waktu tiba serta ketidakpastiannya. Pada penelitian ini terdapat modifikasi dalam penentuan ketidakpastian waktu tibanya. Selain itu juga terdapat penambahan dalam proses penentuan waktu tiba yang akan digunakan, yaitu dilakukan perbandingan waktu tiba antar stasiun yang merekam untuk melihat konsistensi dari suatu kejadian gempa. Diagram alir dari algoritma filter picker yang digunakan dalam penelitian ini dapat dilihat pada Gambar 2

Terdapat 5 parameter input yang dibutuhkan dalam algoritma filter picker ini yaitu rentang waktu panjang atau perata-rataannya (Tlong), rentang waktu perhitungan filter (Tfilter), batas pendeteksian awal (batas 1), batas pendeteksian validasi (batas 2), dan rentang waktu validasi (Tup). Pada makalah ini setiap parameter yang digunakan merupakan nilai-nilai standar atau yang direkomendasikan, optimasi parameter yang digunakan menggunakan metode yang diajukan oleh Vassallo dkk. (2012). Dengan memasukan nilai frekuensi sampling saat melakukan pengambilan data, maka nilai masing-masing parameter Tlong, Tfilter, batas 1, batas 2, dan Tup secara berurutan adalah 5 detik, 3 detik, 10, 10, dan 0.2 detik. Terdapat delapan nilai band frekuensi filter yang digunakan, masing-masing nilai frekuensi tersebut adalah 50, 25, 12.5, 6.25, 3.13, 1.57, 0.79, dan $0.39 \mathrm{~Hz}$. Nilai frekuensi filter yang digunakan ini harus mencakup frekuensi dominan dari waveform kejadian gempa yang akan diten- tukan waktu tiba gelombangnya. Apabila frekuensi dominan gempa dengan frekuensi filter memiliki perbedaan yang cukup besar, akibatnya pendeteksian dan penentuan waktu tibanya menjadi tidak efektif. Perlu diperhatikan bahwa semakin banyak variasi nilai frekuensi yang digunakan maka waktu yang dibutuhkan akan semakin lama.

Proses filter kemudian dilakukan menggunakan kedelapan nilai frekuensi yang disebutkan sebelumnya. Kemudian setiap rekaman yang sudah difilter menggunakan nilai masing-masing frekuensi tersebut dihitung kurva karakteristiknya $(\mathrm{CF})$. Kurva karakteristik merupakan nilai parameter yang didapatkan dari transformasi informasi yang terkandung dalam data seismogram menggunakan suatu persamaan tertentu. Kemampuan suatu algoritma penentuan waktu tiba otomatis dalam melakukan identifikasi dan menentukan waktu tiba berbagai fasa gelombang sangat bergantung kepada kurva karakteristik yang dihasilkannya. Semakin besar separasi dan konsistensi dari kurva karakteristik dalam memisahkan antara fasa gelombang kejadian gempa dengan ambient noise, maka kualitas penentuan waktu tibanya juga akan semakina baik. Dalam makalah ini kurva karakteristik untuk rekaman pada setiap nilai frekuensi filternya dapat dihitung menggunakan persamaan 1 berikut ini.

$$
C F_{n}(i)=\frac{X_{n}-\operatorname{mean}\left(X_{n}(i-1)\right)}{\operatorname{Std}\left(X_{n}(i-1)\right)}
$$

Dimana $\mathrm{n}$ adalah nomor band frekuensi, i adalah nomor sampel, X adalah kuadrat dari amplitudo sample ke i yang sudah difilter. Nilai rata-rata dan standar deviasi dihitung dalam rentang waktu perata-rataannya sampai satu sampel sebelum titik sampel yang akan dihitung nilai kurva karakteristiknya.

Selanjutnya kurva karakteristik gabungan untuk merepresentasikan data rekaman ini didapatkan dengan mencari nilai maksimal untuk setiap titik data diantara semua kurva karakteristik yang ada (dalam paper ini mencari nilai maksimum diantara kedelapan frekuensi terebut). Hasil dari proses filter dan pembentukan kurva karakteriknya diilustrasikan menggunakan Gambar 3, data seismogram yang digunakan berasal dari kejadian gempa tanggal 6 September 2018 yang terekam pada stasiun SP06.

Penentuan waktu tiba diletakan pada waktu tertentu, apabila kurva karakteristik gabungan lebih besar sama dengan batas 1 yang sudah ditetapkan sebelumnya. Untuk menghindari waktu tiba akibat spike, digunakan integral kurva karakteristik gabungannya, dari waktu yang ditetapkan sampai dengan Tup. Apabila nilai integral tersebut melebihi nilai batas 2 dikali dengan Tup (dalam hal ini nilainya adalah 2), maka waktu tiba didefinikan pada titik sampel tersebut. Agar penentuan waktu tiba satu kejadian gempa tidak terlalu banyak, apabila waktu tiba sudah ditentukan maka waktu tiba selanjutnya baru bisa didefiniskan kembali jika kurva karakteristik gabungan sudah turun di bawah 2 .

Nilai ketidakpastian waktu tiba otomatis dalam penelitian ini ditentukan berdasarkan waktu mulai terjadinya peningkatan dari kurva karakteristik gabungan sampai pada kemunculan maksimum lokal pertamanya. Hal ini dilakukan untuk mengetahui seberapa jelas onset kejadian gempa yang terekam. Apabila onset kejadian suatu kejadian gempa 
yang terekam cukup besar maka waktu dari minimum lokal ke maksimum lokalnya akan kecil, pendekatan ini cukup baik untuk mengkuantifikasi ketidakpastiannya. Hal ini dilakukan atas dasar asumsi bahwa apabila suatu kejadian gempa yang terekam memiliki onset yang jelas maka nilai ketidakpastian penentuan waktu tibanya menjadi kecil.

Pemilihan waktu tiba yang akan digunakan berdasarkan perbandingan hasil waktu tiba antar stasiun bertujuan untuk meminimumkan kemungkinan terjadinya pendeteksian kejadian gempa yang kurang tepat. Apabila terjadi gempa dengan energi yang cukup besar maka akan banyak stasiun yang dapat merekamnya. Sedangkan sumber noise yang kuat misalkan orang berjalan, atau kendaraan bermotor sifatnya sangat lokal dan waktu terjadinya sangat acak (tidak ada hubungan antar stasiunnya). Sehingga dengan memanfaatkan kedua fakta ini, kesalahan penentuan waktu tiba akibat sumber noise yang acak dapat diminimumkan dengan melihat konsistensi waktu tiba antar stasiunnya. Tentu saja kesalahan waktu tiba ini tetap akan terjadi jika terdapat sumber noise yang banyak disekitar stasiun, tetapi peluang kemunculan noise di beberapa stasiun secara bersamaan cukup kecil.

Perbandingan antar stasiun untuk menentukan suatu waktu tiba berasal dari kejadian gempa atau bukan membutuhkan 2 parameter yaitu jumlah stasiun minimal yang mendeteksi dan rentang waktu evaluasinya. Semakin besar nilai jumlah stasiun minimal maka kemungkinan terjadinya kesalahan identifikasi kejadian gempa semakin kecil. Tetapi konsekuensinya adalah gempa-gempa dengan magnitudo yang kecil juga berpeluang tidak terdeteksi. Dalam penelitian ini digunakan jumlah minimal stasiun yang mendeteksi sebanyak 5 stasiun, dan kemudian diubah menjadi 7 dan 9 stasiun untuk melihat pengaruhnya terhadap jumlah kejadian gempa yang terdeteksi. Nilai rentang waktu yang digunakan dapat berasal dari pemodelan kedepan untuk mendapatkan nilai rata-rata maksimal selisih waktu tempuh atau langsung dari rata-rata maksimal selisih penentuan waktu tiba manualnya (jika tersedia). Nilai rentang waktu yang terlalu kecil dapat mengakibatkan hilangnya kejadian gempa, tetapi apabila terlalu besar maka hasil dari proses penghilangan kesalahan identifikasi akibat noise tidak akan maksimal. Dalam penelitian ini nilai rentang waktu yang digunakan adalah 10 detik, didapatkan dari pemodelan kedepan titik-titik grid yang dibuat disekitar daerah penelitian. Pemodelan kedepan untuk mendapatkan waktu tempuh menggunakan metode shooting Snell dan model kecepatan 1-D menggunakan AK135. Setiap titik dicari nilai selisih waktu tempuh maksimalnya, kemudian dihitung nilai rata-rata dari semua titik gridnya. Kedua nilai parameter ini dapat berbeda dari satu pengukuran dengan lainya, dan sangat bergantung kepada konfigurasi penempatan stasiunnya. Selain dengan metode ini, mengklasifikasikan waktu tiba menjadi kejadian gempa juga dapat dilakukan dengan menggunakan metode-metode lainya (Kurzon dkk., 2014).

\section{HASIL DAN ANALISIS}

Hasil perbandingan penentuan waktu tiba manual dengan otomatis dari algoritma filter picker ditunjukkan pada Gambar 4. Kejadian gempa yang digunakan ini sama dengan yang dipakai dalam ilustrasi pembentukan kurva karakter- a)

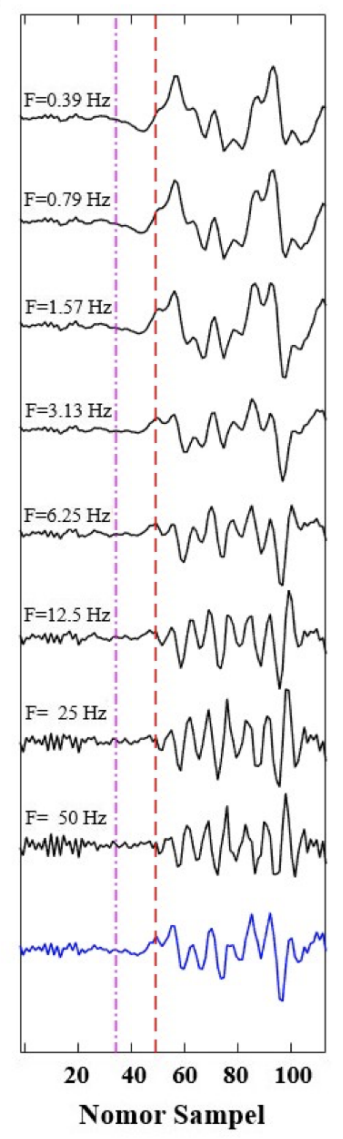

b)

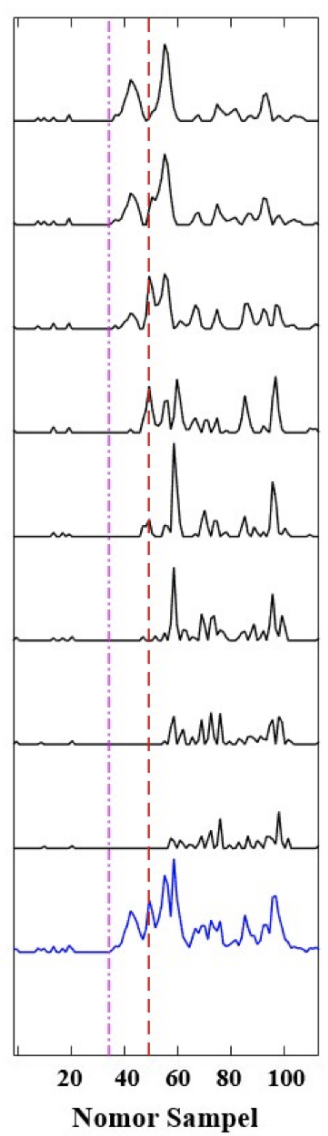

Gambar 3. a) Hasil filter komponen vertikal data seismogram ternormalisasi menggunakan berbagai nilai frekuensi, trace paling bawah merupakan data rekaman awal b) Kurva karakteristik dari masing-masing trace dengan skala masing-masing 0 sampai 50, kurva paling bawah merupakan kurva karakterstik gabungan; garis putus-putus berwarna merah merupakan posisi dari waktu tiba gelombang $\mathrm{P}$ yang ditentukan secara manual, sedangkan titik garis berwarna ungu adalah hasil dari otomatis

istik dalam Gambar 3 sebelumnya. Contoh ini merupakan hasil yang kurang ideal, tetapi sangat baik untuk memberikan gambaran mengenai perbedaan penentuan waktu secara manual dengan otomatis. Pada stasiun BB03 fasa gelombang $\mathrm{P}$ tidak terdeteksi secara otomatis tetapi pada fase gelombang $\mathrm{S}$ terdeteksi secara otomatis, sedangkan pada stasiun ST03 dan BB07 kedua fasanya terdeteksi. Hal tersebut dapat menyebabkan masalah saat ingin melakukan perbandingan hasil penentuan waktu tiba gelombang $\mathrm{P}$ secara otomatis dan manual, karena algoritma penentuan waktu tiba yang digunakan tidak dapat mengidentifikasi jenis fasa gelombangnya.

Membandingan hasil penentuan waktu tiba yang dilakukan secara manual dengan otomatis merupakan suatu permasalahan yang membutuhkan penanganan tersendiri. Hal ini karena bisa saja suatu kejadian gempa dapat ditentukan waktu tibanya secara manual, tetapi tidak terdeteksi dalam penentuan waktu tiba secara otomatis dan begitu juga sebaliknya. Selain itu seperti yang ditunjukan pada Gambar 4 bahwa penentuan waktu tiba secara otoma- 


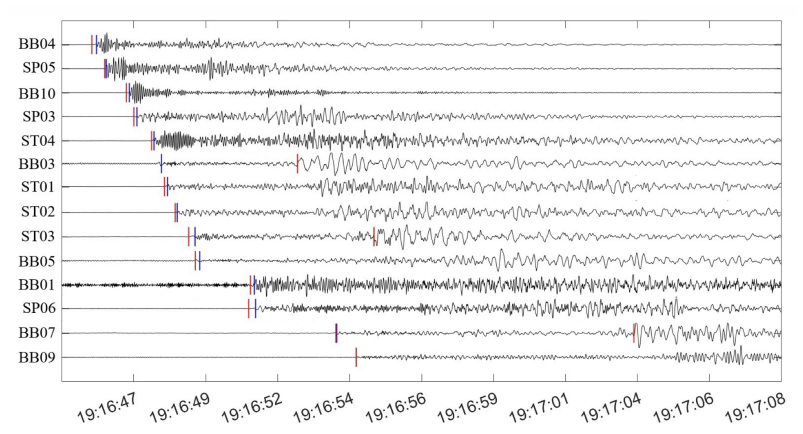

Gambar 4. Contoh perbandingan hasil penentuan waktu tiba gelombang P secara manual (garis berwarna biru), dan otomatis (garis berwarna merah) pada kejadian gempa tanggal 6 September 2018. Urutan stasiun dari atas ke bawah didasarkan pada waktu tiba gelombang $\mathrm{P}$ manual yang tercepat.

tis tidak dapat membedakan fasa gelombang $\mathrm{P}, \mathrm{S}$, ataupun noise padahal disini ingin dilakukan perbandingan akurasi penentuan waktu tiba gelombang $\mathrm{P}$ saja. Oleh karena itu dilakukan pemotongan data rekaman 60 detik sebelum dan sesudah waktu tiba gelombang P paling minimum suatu kejadian gempa, kemudian seismogram ini dijadikan input algoritma penentuan waktu tiba yang telah dijelaskan pada bagian sebelumnya. Fasa gelombang $\mathrm{P}$ dinyatakan berhasil dideteksi, apabila maksimal selisih antara penentuan waktu tiba fasa gelombang $\mathrm{P}$ secara otmomatis dan manual sebesar 2 detik. Jika terdapat lebih dari satu waktu tiba otomatis yang selisihnya kurang dari 2 detik, disini hanya akan digunakan satu saja dengan nilai selisih terkecil. Hal ini perlu dilakukan agar dapat mengevaluasi performa algoritma ini dalam mendeteksi gelombang $\mathrm{P}$ secara benar, terutama dalam hal kuantitasnya.

Nilai selisih positif artinya waktu tiba otomatis lebih lambat dibandingkan manual, dan sebaliknya apabila selisih bernilai negatif. Berdasarkan Gambar 5a dan 5b terlihat adanya perbedaan jumlah waktu tiba yang cukup besar, hal ini lebih dipengaruhi oleh adanya perbedaan jumlah stasiun bertipe broadband dengan short period. Sehingga untuk membandingkannya secara lebih objektif, digunakan persentase jumlah yang terdeteksi secara otomatis dengan manual untuk masing-masing tipe instrumen. Nilai persentase keterdeteksian untuk stasiun bertipe short period adalah 81.5 persen sedangkan broadband adalah 85.3 persen. Nilai persentase untuk seismometer broadband lebih besar daripada short period, tetapi algoritma filter picker dapat dinilai cukup berhasil untuk kedua tipe seismometer ini. Dalam gambar ini juga dapat terlihat adanya kemiripan pola distribusi histogram residual waktu tiba gelombang $\mathrm{P}$ serta terdapat konsistensi nilai rata-rata(-0.06 untuk BB dan -0.04 untuk SP) dan standart deviasi(0.33 untuk BB dan 0.25 untuk SP) dari kedua tipe alat ini. Berdasarkan nilai persentase dan pola histogram yang dihasilkan dari kedua jenis seismometer tersebut, maka dapat dikatakan bahwa algoritma filter picker dapat digunakan untuk alat bertipe broadband dan short period yang belum dilakukan proses koreksi instrumen sebelumnya.

Setelah mengetahui bahwa algoritma filter picker ini dapat digunakan untuk instrumen bertipe broad band dan short period, kemudian dilakukan evaluasi performa dari
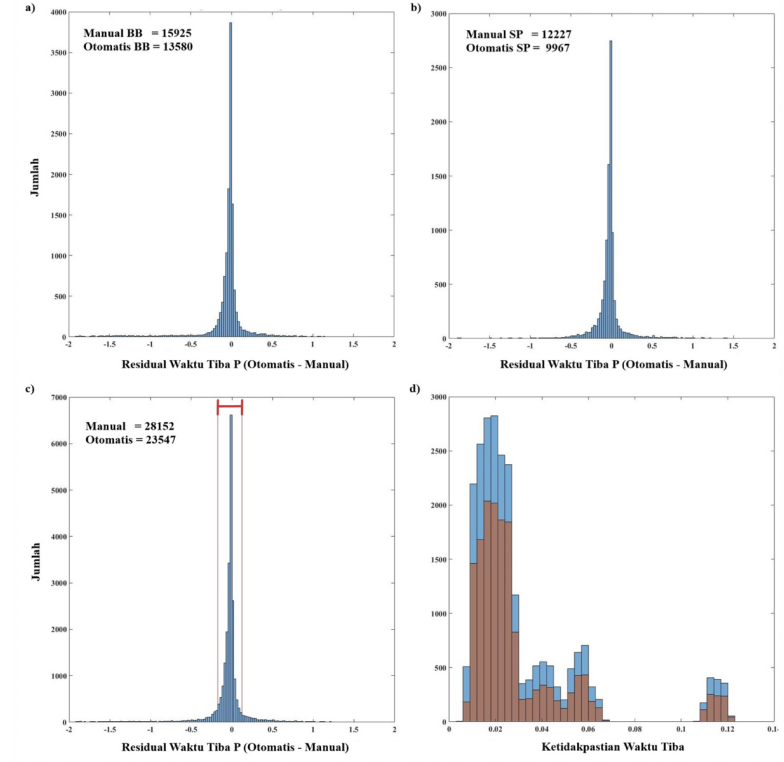

Gambar 5. Histogram selisih penentuan waktu tiba gelombang $\mathrm{P}$ secara otomatis dengan manual a) untuk seismometer bertipe broad band (BB) saja, b) untuk short period (SP) saja, c) gabungan keduanya, d) adalah ketidakpastian dari penentuan waktu tiba otomatis untuk semua data (batang berwarna biru), dan untuk data yang memiliki selisih waktu tiba antara -0.1 sampai 0.1 (batang berwarna merah)

algoritma ini. Evaluasi dilakukan menggunakan hasil histogram gabungan (Gambar 5.c), nilai parameter skewness, standar deviasi, rata-rata, median, dan modus secara berurutan adalah $-1.41,0.29,-0.05,-0.02$, dan -0.01. Dari histogram ini, distribusi 85 persen hasil yang didapatkan memiliki selisih kurang dari 0.2 detik. Berdasarkan nilai skewnessnya, hasil dari penentuan waktu tiba secara otomatis memiliki kecenderungan untuk mendapatkan nilai yang lebih cepat daripada waktu tiba secara manual. Tetapi dengan nilai parameter standart deviasi yang kecil, serta nilai rata-rata, median, dan modus yang disekitar nol, dapat dikatakan bahwa metode ini cukup akurat dan stabil atau presisi. Kencenderungan dari penentuan waktu tiba otomatis yang menghasilkan nilai yang lebih cepat ini juga didemonstrasikan dalam Gambar 3 dan 4 sebelumnya. Hal ini lebih diakibatkan oleh faktor subjektifitas atau preferensi orang yang menentukan waktu tiba berdasarkan frekuensi yang tinggi saja, sedangkan algoritma ini meninjau dari frekuensi yang rendah sampai yang tinggi.

Selanjutnya dilakukan analisa apakah terdapat pengaruh dari kejelasan onset waktu tiba terhadap selisih yang ada pada penentuan waktu tiba otomatis dan manual. Parameter yang digunakan untuk mengevaluasi hal ini adalah ketidakpastian penentuan waktu tiba otomatis yang telah dijelaskan pada bagian sebelumnya. Pada Gambar 5.d terlihat bahwa pola histogram ketidakpastian untuk data yang memiliki selisih lebih dari -0.1 dan kurang dari 0.1 cukup merata dan serupa dengan pola histogram keseluruhan data. Dalam hal ini, tidak terlihat adanya hubungan atau kencenderungan dari selisih antara waktu tibanya dengan kejelasan onset. Sehingga dapat dikatakan bahwa selisih antara waktu tiba otomatis dengan manual ini lebih disebabkan oleh tidak 


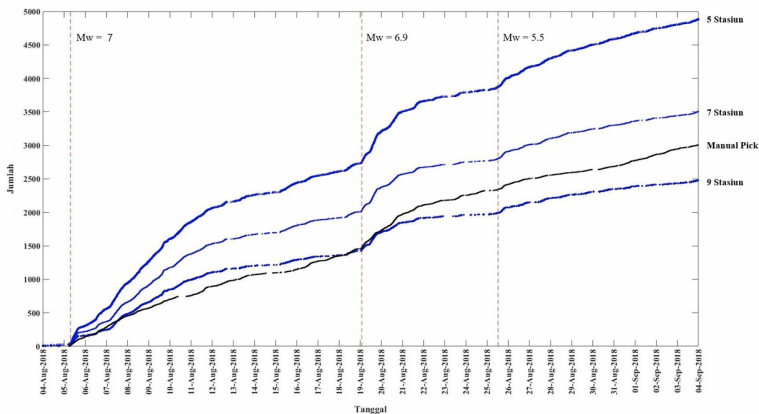

Gambar 6. Kumulatif jumlah kejadian gempa yang dideteksi dari tanggal 4 Agustus 2018 sampai 4 September 2018 secara manual (titik berwarna hitam) dan otomatis (titik berwarna biru), garis putus-putus berwarna merah menunjukan waktu terjadinya beberapa gempa dengan magnitudo besar yang terjadi disekitar daerah penelitian dengan menggunakan jaringan stasiun lokal.

sesuainya parameter penentuan waktu tiba otomatis dengan prefrensi yang dimiliki saat melakukannya secara manual. Hasil ini tidak dapat diartikan sebagai suatu kegagalan algorithmic, tetapi menunjukan pentingnya melakukan penyesuaian parameter-parameter inputnya untuk meningkatkan akurasi penentuan waktu tibanya.

Kemudian dilakukan perbandingan jumlah kejadian gempa yang terdeteksi secara manual dengan otomatis yang telah diklasifikasikan, sesuai dengan penjelasan pada bagian sebelumnya. Dalam melakukan perbandingan ini berbeda dengan saat melakukan analisa akurasi penentuan waktu tiba. Disini kejadian gempa terdeteksi secara otomatis digunakan seluruhnya, tidak terbatas hanya pada kejadian gempa yang terdeteksi secara manual saja. Hal ini dilakukan untuk mendapatkan gambaran mengenai potensi kemampuan algoritma filter picker untuk mendeteksi kejadian gempa dan tingkat keselarasan atau konsistensinya terhadap pendeteksian secara manual.

Hal pertama yang teramati dari hasil pada Gambar 6 adalah jumlah stasiun minimum pada suatu rentang waktu tertentu yang digunakan untuk mengklasifikasikan waktu tiba otomatis menjadi suatu event sangat mempengaruhi jumlah event kumulatif yang dihasilkan. Semakin sedikit jumlah stasiun menyebabkan peluang waktu tiba diklasifikasikan menjadi suatu kejadian gempa menjadi semakin besar. Hal ini dapat dipahami bahwa, jumlah stasiun minimal secara tidak langsung berkaitan dengan rasio sinyal dengan noisenya. Semakin besar magnitudo suatu gempa maka nilai rasio sinyal dengan noisenya akan tinggi dan stasiun yang dapat mendeteksinya juga akan semakin bertambah banyak. Oleh karena jumlah kejadian gempa dengan nilai magnitudo besar akan lebih sedikit dibandingkan dengan magnitudo kecil, sesuai dengan hukum Gutenberg-Richter. Implikasi dalam hal ini adalah semakin besar jumlah stasiun minimal yang mendeteksi suatu kejadian gempa, jumlah kumulatif kejadian gempa akan semakin sedikit. Apabila kita menggunakan parameter minimal 5 stasun maka maksimal jumlah kejadian gempa yang terdeteksi menjadi 2 kali lipat dari pendeteksian secara manual. Disini digunakan kata maksimal karena belum tentu semua yang terdeteksi sebagai kejadian gempa saat melakukan pendeteksian secara otomatis merupakan kejadian gempa.
Hasil pada Gambar 6 juga menunjukan adanya keselarasan pola kurva kumulatif kejadian gempa yang baik antara penentuan secara otomatis dan manual. Semua kurva kumulatif memiliki trend yang cukup serupa yaitu adanya peningkatan jumlah yang cukup tinggi setelah terjadi gempa bermagnitudo cukup besar di sekitar daerah penelitian. Gempa bermagnitudo besar seperti pada tanggal 19 Agustus 2018 menghasilkan peningkatan jumlah yang lebih besar dan dalam rentang waktu yang lebih lama dibandingkan dengan bermagnitudo yang lebih kecil pada tanggal 25 Agustus 2018 (Gambar 6). Hal ini sudah sesuai dengan hukum Omori mengenai laju jumlah kehadiran aftershock terhadap besarnya magnitudo gempa terjadi.

\section{KESIMPULAN}

Pada makalah ini kami mengimplementasikan dan mengevaluasi hasil dari algoritma filter picker untuk data rekaman aftershock gempa Lombok menggunakan jaringan stasiun lokal. Evaluasi dilakukan dengan membandingkan hasil penentuan waktu tiba gelombang $\mathrm{P}$ dan hasil kumulatif kejadian gempa teridentifikasi yang didapatkan secara manual dengan otomatis. Hasil selisih penentuan waktu tiba otomatis dengan manualnya menunjukan distribusi yang baik, lebih dari 85 persen hasilnya memiliki selisih yang lebih kecil dari 0.2 detik.

Nilai parameter standar deviasi yang kecil, dan nilai rata-rata, median, modus yang disekitar nol, menunjukan bahwa metode ini cukup stabil dan akurat. Tetapi nilai parameter skewnessnya memberikan nilai -1.41 yang artinya, waktu tiba otomatis memiliki kecenderungan cukup kuat untuk menghasilkan waktu tiba yang lebih cepat dibandingkan dengan manualnya, sehingga diperlukan penyesuaian nilai parameter input yang digunakan. Kemudian jumlah kejdian gempa yang terdeteksi sangat bergantung kepada kriteria jumlah stasiun yang digunakan, tetapi dapat teramati adanya keselarasan pola kurva kumulatif kejadian gempa secara otomatis dan manualnya.

Hasil pola histogram selisih waktu tiba otomatis dan manualnya untuk alat bertipe short period dan broad band tidak menunjukan perbedaan yang berarti. Aplikasi algoritma ini pada kedua tipe alat menunjukan performa identifikasi gelombang $\mathrm{P}$ yang baik, sebesar 81.5 persen dari gelombang $\mathrm{P}$ secara manual berhasil diidentifikasi untuk instrumen bertipe short period dan 85.3 persen untuk intrumen bertipe broad band. Dengan hanya menggunakan parameter input yang direkomendasikan, dan tanpa melakukan koreksi instrument sebelumnya filter picker tebukti dapat memberikan hasil waktu tiba yang cukup baik.

Berdasarkan analisis yang telah dilakukan terhadap hasil penelitian ini, maka dapat disimpulkan algoritma filter picker sangat efektif untuk mengidentfikasi dan menentukan waktu tiba gelombang $\mathrm{P}$ dan dapat digunakan untuk data seismogram dari alat bertipe broad band ataupun short period.

\section{UCAPAN TERIMA KASIH}

Penulis mengucapkan terimakasih kepada Laboratorium Vulkanologi dan Geothermal ITB,EOS, BMKG, dan 
PVMBG yang telah membantu dalam pengambilan data untuk penelitian ini.

\section{DAFTAR PUSTAKA}

Allen, R. V. (1978): Automatic earthquake recognition and timing from single traces, Bulletin of the Seismological Society of America, 68, $1521-1532$.

Baer, M. dan Kradolfer, U. (1987): An automatic phase picker for local and teleseismic events, Bulletin of the Seismological Society of America, 77, 1437 - 1445.

Baillard, C., Crawford, W. C., Ballu, V., Hibert, C. dan Mangeney, A. (2014): An automatic kurtosis-based P- and S-phase picker designed for local seismic networks, Bulletin of the Seismological Society of America, 104, no.1, $1-16$.

De Meersman, K., Kendall, M., dan Vand der Baan, M. (2009): The 1988 Valhall microseismic data set: An integrated study of relocated source, seismic multiplets, and S-wave splitting, Geophysics, 74, no.5, B183-B195.

Earle, P. S., dan Shearer, P. M. (1994): Characterization of global seismograms using an automated picking algorithm, Bulletin of the Seismological Society of America, 84, 366-376.

Han, L., Wong, J., dan Bancroft, J. (2009): Time picking and random noise reduction on microseismic data: CREWES Research Report, 21, 1-13.

Kurzon, I., Vernon, F. L., Rosenberger, A., dan Ben-Zion, Y. (2014): Real-time automatic detectors of $\mathrm{P}$ and $\mathrm{S}$ waves using singular value decomposition, Bulletin of the Seismological Society of America, 104, 1696 - 1708.

Leonard, M., dan Kennett, B. L. N. (1999): Multicomponent autoregressive techniques for the analysis of seismograms, Physics of The Earth and Planetary Interiors, $113,247-263$.

Lomax, A., Satriano, C., dan Vassallo, M. (2012): Automatic picker developments and optimization: filterpicker a robust, broadband picker for real-time seismic monitoring and earthquake early warning, Seismological Research Letters, 83, 531-540.

Ross, Z. E., dan Ben-Zion, Y. (2014): Automatic picking of direct P, S seismic phase and fault zone head waves, Geophysical Journal International, 199, 368-381.

Vassallo, M., Satriano, C., dan Lomax, A. (2012): Automatic picker developments and optimization: a strategy for improving the performance of automatic phase picker, Seismological Research Letters, 83, 541-554. 